\title{
GAMIFIKÁLT KÖZÖSSÉGI MEGOLDÁS HASZNÁLATA A KEDVEZŐBB MUNKAHELYI LÉGKÖR KIALAKÍTÁSA ÉRDEKÉBEN
}

Az utóbbi évtizedben egyre jelentősebb figyelmet kapnak a munkavállalók cég iránti elköteleződésével, annak lehetséges növelésével kapcsolatos vizsgálatok, melynek egyik forrása lehet a megfelelő munkahelyi légkör kialakítása.

Ebben a kutatásban a szerzők arra keresték a választ, hogy egy gamifikációs elvek mentén felépített online szolgáltatás mennyire alkalmas a vállalaton belüli szociális környezet javítására. A kutatásban egy olyan eszköz felhasználói bázisát, valamint az eszköz rájuk gyakorolt hatását vizsgálták, amely gamifikációs elemek segítségével sportos és játékos eseménysorozatok egyszerű lebonyolítását teszi lehetővé. Munkájukban elemezték a munkahelyi légkör változását, a munkatársak közötti kapcsolati háló kiterjedésének és minőségének alakulását, valamint a sportolási szokások módosulását.

Eredményeik azt mutatják, hogy a gamifikált online szolgáltatás használatakor a felhasználók jobb munkahelyi légkörről számoltak be, számos új embert ismertek meg, és az alkalmazás motiválta őket a testedzés életvitelbe iktatására.

\section{Kulcsszavak: gamifikáció, munkahelyi légkör, alkalmazotti jóllét, kapcsolati háló, online eszköz}

$\mathrm{A}$ játékosítás (gamification vagy gamifikáció) az elmúlt évek egyik legnépszerübb stratégiája a munkahelyi motivációs módszertár megújítására. A játékosítással foglalkozó szakemberek a módszer lényegét úgy foglalják össze, hogy a játékosítás nem más, mint a játéktevékenység mechanikai és dinamikai elemeinek alkalmazása alapvetően nem játékos közegben egy kívánt viselkedésforma elősegítésének céljából (Bunchball, 2010). Más kutatók a játékosítás lényegét abban látják (Carter, 2012), hogy a játékelemek segítségével a felhasználókat az elkötelezésük által olyan cselekedetekre ösztönözze, amelyeket más környezetben nem feltétlenül tennének meg, azaz minden a felhasználói élmény és az elköteleződés érdekében történik.

A legtöbb játék, játékosított rendszer az alábbi alkatrészek (1. ábra) felhasználásával épülhet fel (Werbach Hunter, 2012; Hunicke, 2004):

- játékelemek,

- játékmechanizmusok,

- játékdinamika,

- játékélmény (fun).

1. ábra

A játékosítás alkotórészei

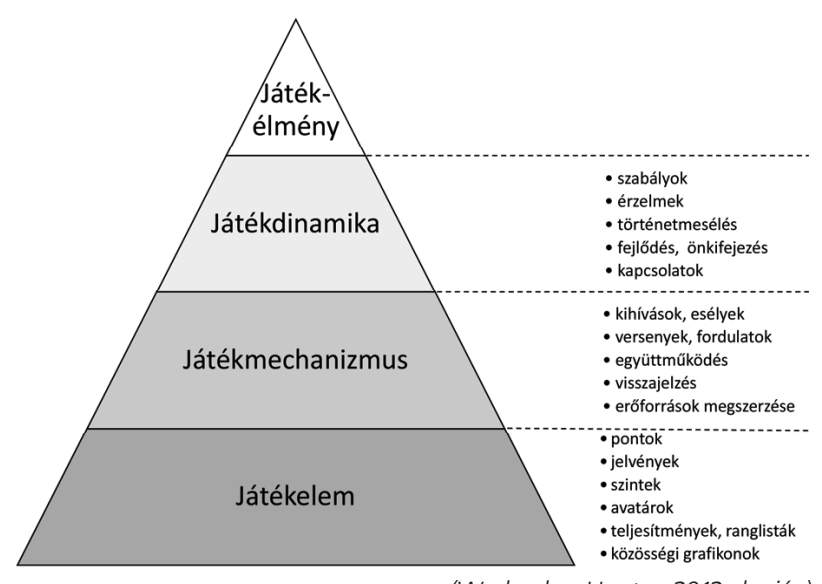

(Werbach - Hunter, 2012 alapján)
A hierarchia legalsó szintjén a játékelemek foglalnak helyet. Ezek azok a konkrét elemek, melyekkel a játék első használatakor a felhasználó már szembesül: pontokat gyüjthet, csapatokat alkothat, kialakíthatja saját karakterét vagy küldetéseket teljesíthet (Werbach - Hunter, 2012).

A következő szint a játékmechanizmusok, melyek leírják, hogy az egyes játékelemek miként kapcsolódnak egymáshoz, illetve hogyan határozzák meg a felhasználó egyes lépéseit és állapotait. Magába foglalja továbbá a játék előrehaladását meghatározó iránymutatásokat, illetve egy előforduló eseményre várható reakciókat.

A dinamika a játékosok viselkedése és egymáshoz való viszonya, amelyet az előbb ismertetett játékelemek és mechanizmusok váltanak ki, illetve ösztönöznek. A dinamikákat befolyásolja a felhasználó természete és tapasztalata. Egy kockázatkerülő, befelé forduló játékos más viselkedési mintával rendelkezik, mint egy kifejezetten kockázatos helyzeteket kereső felhasználó, aki hajlamos extrajuttatások reményében könnyebben felvállalni egy hosszabb játék eredményét is veszélyeztető helyzetet (Werbach - Hunter, 2012).

Fontos megjegyeznünk, hogy a játékosított rendszerek az esetek túlnyomó részében integráltan jelennek meg egy adott online platformon. Az alkotóelemek integrálásától azonban még nem lesz egy rendszerből sikeresen gamifikált alkalmazás, ezért van szükség a játéktervezési szemléletre, mely a felhasználónak nyújtott szórakoztató élményt, a fun-t helyezi a középpontba. Ez az „élmény” több formát is ölthet a problémamegoldástól kezdve a csapatmunkán át a győzelemig rengeteg esemény tudja szórakoztatni a felhasználókat.

Összességében elmondható, hogy a játékosítás kapcsán számos eszköz áll rendelkezésre, amelyek az üzleti folyamatokat érdekesebbé tehetik. Ugyanakkor nem szabad megfeledkezni arról, hogy egy folyamat attól még nem lesz a felhasználók számára izgalmas, és nem fog elköteleződést kiváltani, ha átgondolatlanul alkalmazunk játékelemeket. Annak érdekében, hogy egy játékosított al- 
kalmazás elérje a kívánt hatást, motiválónak és addiktívnak kell lennie, emellett folyamatos bátorítást szükséges nyújtania, hogy a különböző lehetőségeken keresztül a felhasználó a rövid távú céljait sorra elérje, de mindemellett fenn kell tartania a lehetőséget a hibázásra, a bukásra és az újrapróbálkozásra is (O’Donovan, 2013).

A játékosítás a modern üzleti tudományokban már évek óta jelenlévő elképzelés és kutatási irány. A Gartner Group egy 2012-es elörejelzése szerint napjainkra a cégek több mint 70 százaléka használni fogja, a játékosítási üzlet (a világon játékosított alkalmazásokra, szolgáltatásokra és eszközökre költött összeg) 2018-ra elérheti az 5,5 milliárd dollár értéket is (Gartner, 2012).

A gamifikáció sikere érthető, mivel az az elképzelés, hogy a játéktervezési tapasztalatok és a viselkedési közgazdaságtan eredményeinek felhasználásával a folyamatok hatékonyabbá tehetők, és ezzel a használók motiváltsága, elköteleződése nő, erős pszichológiai alapokra épített és könnyen eladható, hiszen a játékipar bevételi statisztikái igen látványosak, és lenyűgöző, hogy a játékosok mennyi időt töltenek egy-egy program használatával.

A munkavállalók cég iránti elköteleződése pedig alapvető az üzleti vállalkozások sikeréhez. Mit is értünk elköteleződés alatt? Az elköteleződés, elkötelezettség nem új fogalom, a kétezres évek elejétöl pedig egyre gyakrabban használt kifejezéssé vált az emberi erőforrással foglalkozó szakemberek körében. Magát a fogalmat sokan sokféleképpen definiálják, számunkra a munkavállalói elkötelezettség nem más, mint a munkavállalók hajlandósága és képessége, hogy hozzájáruljanak a vállalati sikerhez. Az elkötelezettség tehát annak a mértéke, hogy a munkavállalók önszántukból mennyi extra erőfeszítést, energiát, kreativitást és szenvedélyt hajlandóak beletenni a munkájukba (Towers Perrin, 2008).

A munkavállalói elkötelezettségnek számos olyan, a munkáltató szempontjából elönyös következménye van, mint a nagyobb megtartási arány, a kevesebb hiányzás, a vállalati célok és stratégia jobb megértése. Ezen túlmenően Harter és szerzőtársai munkájukban rámutattak arra is, hogy a munkavállalói elköteleződés és a pénzügyi eredmény között közvetlen kapcsolat áll fenn (Harter Schmidt - Hayes, 2002). A Gallup 2013-ban közölt kutatásaiból (Gallup, 2013) kiderül, hogy a munkavállalók elköteleződésének hiánya az Egyesült Államoknak évente körülbelül 450-550 milliárd dollárjába kerülhet. Így nem meglepő, hogy a vállalatok törekszenek arra, hogy az elkötelezettség mértékét növeljék (Shuck - Rose, 2013), és a menedzsment a munkavállalói elköteleződés kialakítását kiemelt prioritásként kezelje (Shuck - Wollard, 2010; Schaufeli, 2012).

A munkavállalók elköteleződésének vizsgálatával számos cég foglalkozik. Az Aon Hewitt a téma egyik szakértő tanácsadó cége, amely évente jelenteti meg felmérései eredményeit. 2017-es vizsgálatuk szerint (Hewitt, 2017) a világon a munkavállalók 63\%-a érzi elkötelezettnek magát a munkáltatóhoz, és ez az érték 58\%, ha csak az európai értékeket nézzük. Számos további tanulmány számol be az elkötelezettség csökkenése mellett a munkahelyi megelégedettség visszaeséséről is.
A vállalatok számára tehát alapvetően fontos lépés, hogy megismerjék és tudatosítsák azokat a tényezőket, amik az elkötelezettség kialakulásában kulcsszerepet játszanak, tisztában legyenek azokkal a mozgatórugókkal, amik elköteleződésre késztetik a munkavállalókat a szakmájuk vagy a szervezetük iránt. Az Aon Hewitt cég tanulmányában (Hewitt, 2017) ezeket a tényezőket elégedettségi dimenzióknak nevezi, és az elemzésük szerint az elégedettség elöfeltétele az elkötelezettségnek, és a tényezőkkel való elégedettségük az, ami megalapozza a munkavállalók elkötelezettségét.

A különböző csoportosításokat összevetve kilenc kategóriába lehet sorolni az elkötelezettség növelésében szerepet játszó tényezőket:

- jövőkép,

- lehetőségek,

- munka és feladatok,

- önrendelkezés,

- szociális környezet,

- kommunikáció,

- környezet,

- vállalati értékek és gyakorlatok,

- javadalmazás és elismerés.

A kutatásunkban használt gamifikációs megoldás a kilenc kategóriából a vállalaton belüli szociális környezet javításában, a munkahelyi kapcsolatok kialakításában segíthet. A csapathoz való tartozás, együttmüködés, az, hogy kialakulnak-e barátságok a munkatársak között, a közösséghez tartozás érzete, vagy éppen ellenkezőleg, a személytelen és antiszociális környezet mind erősen befolyásolják az elkötelezettség szintjét (Szabó, 2016).

A gamifikáció lehetőségének elemzéséhez egy online elérhető (Battlejungle, 2017) alkalmazást választottunk, amelynek célkitüzése a munkatársak közti kapcsolatok számának és minőségének, valamint a munkahelyi légkörnek a fejlesztése. A szoftver a munkatársak közötti sportjellegü események szervezéséhez és ösztönzéséhez nyújt támogatást. Különböző sportszámokban kínál megmérettetési lehetőséget, amelyek alapvetően két nagy csoportra oszthatók: az egymás elleni összecsapásokon alapuló bajnokságokra, úgymint az asztalitenisz vagy a futball, valamint az egyéni vagy csapat által elért teljesítmény összehasonlításán alapuló eseményekre, mint például a futás. A gamifikáció lehetőségeit számos más alkalmazás (Endomondo, Nike+ Running, Fitbit One, Fitocracy, Adidas MiCoach) is használja a rendszeres testedzés motiválására, de ezek többnyire csak az „egyéni” sporttevékenységeket, mint a futást, a kerékpározást, a túrázást támogatják, de nem teszik lehetővé csapatjátékok szervezését.

Megjegyzendő a több tanulmány által bizonyított tény, miszerint a sport és a testedzés mint viselkedés már önmagában hatékony stresszcsökkentő hatású. A rendszeres testedzésnek természetes hozadéka a mentális jólét, a wellbeing javulása, amelynek szervezeti következménye a hiányzások számának csökkenése, a csökkenő kilépési arány, a megnövekedett teljesítmény, a baleseti ráta csökkenése is (Houtman, 2007). Így a kutatásunk fontos 
kérdése volt, hogy vajon a gamifikációs alkotóelemeket tartalmazó alkalmazás ösztönözte-e az alkalmazottakat a rendszeres testedzés életvitelbe iktatására, illetve következetes fenntartására vagy sem.

\section{A játékosok}

Digitális világunkban lassan kortól és nemtől függetlenül mindannyian játékosokká válunk, lépten-nyomon játékokba botlunk. Az Egyesült Államokban például a háztartások 63\%-ában legalább egy személy rendszeresen (hetente legalább 3 órát) játszik. Az átlagos játékos 35 éves, és legalább 13 éve játszik valamilyen számítógépes játékot. Meglepő módon a nemek arányában nincs számottevő különbség, ugyanis a játékosok közel fele, 41\%-a nő (ESA, 2016).

Richard Bartle (Fromann, 2012) véleménye szerint a játékosok játékstílusuk, motivációjuk, magatartásuk és preferenciáik alapján négy csoportba sorolhatók: a gyilkosok (Killers), a felfedezők (Explorers), a társaságiak (Socializers) és a teljesítök (Achievers) csoportjaiba. A modellt a 2. ábra szemlélteti.

2. ábra

\section{A játékosok csoportosítása}

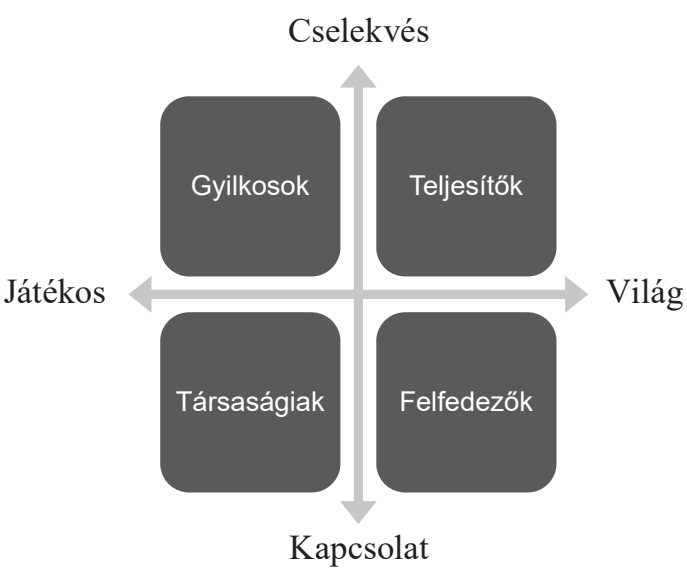

(Fromann, 2012)

A csoportosítás két dimenzió mentén valósul meg: a cselekvés-kapcsolat és a játékos-világ tengelyén, melyek a játékosok érdeklődését mutatják. A teljesítők közé azokat a játékosokat sorolhatjuk, akik az eredményességre törekszenek, és céljuk valamilyen akadály leküzdése, vagy mások elismerésének kivívása. A felfedezők szeretik a határokat feszegetni, és igyekeznek a lehető legtöbbet kihozni az adott játékból. Legfőbb motivációjuk a játékterep feltérképezése és mások megismerése. A társaságiak számára a másokkal való kapcsolattartás és ismerkedés a legfontosabb, gyakran használják a játékok chat funkcióit. A gyilkosok pedig meglehetősen deviáns magatartásmintát vesznek fel a játék során: elsődlegesen a károkozásra, vagy mások játékból való kiiktatására törekszenek.

Több tanulmány is rámutatott (Yee, 2006; Dixon, 2011), hogy a Bartle-féle modell nem feltétlenül létezik ennyire letisztult formában. Egy felhasználó ugyanis többféle magatartást is felvehet játék közben, így a kategóriák átfedést mutathatnak, és nem kölcsönösen kizáró- ak. Hiányosságai ellenére, a modell jó kiinduló pontnak tekinthető.

Az elöző fejezetben már említettük, hogy a gamifikáció lényegesen többet jelent, mint pontok és jelvények kiosztását. Világosan kell látni és tervezni az üzleti célt, és érteni kell a célcsoportot és azok motivációit. Egy sikeres gamifikált alkalmazásban a kihívásoknak mindig illeszkedniük kell a játékos képességeihez, lehetőségeihez (Kenézi, 2015). Fromann (Fromann, 2012) szerint a kulcs az optimális terhelés, ideális beszintezés, ideális jutalomrendszer hármasban keresendő. Ha a játékosoknak értelmes döntési lehetőségeket biztosítunk, azaz a játékos befolyásolni tudja az esélyeit a játékban, akkor ez komoly pluszmotivációt jelenthet, ami a hosszabb távú bekapcsolódás feltétele (Kenézi, 2015).

Werbach és Hunter (Werbach - Hunter, 2012) arra hívja fel a figyelmet, hogy a játék által generált külső motiváció „felfalhatja” a tevékenységhez kapcsolódó belső motivációt - vagyis elfeledtetheti azt az indokot, ami eredetileg, a játék nélkül kapcsolódott a tevékenységhez. Ily módon a játékosok döntései a játék logikájának fognak megfelelni, nem a valódi cél elvárásainak (Kenézi, 2015). Hasonló probléma lehet, ha a játék szereplői a játékra optimalizálják a viselkedésüket, és kihasználják a játék lehetőségeit, akár visszaélve is azokkal (Kenézi, 2015).

A szakirodalomban számos esettanulmányt találunk arra, hogy a gamifikáció eszközeinek segítségével próbálták a munkavállalók, illetve a vásárlók elköteleződését növelni, mint például Freshdesk (Freshdesk), Decoded (Droga5ny, 2011), My Marriott Hotels (Robson et al., 2016), SAP iPad (SAPVoice, 2011). Az esettanulmányok tapasztalata is azt mutatja, hogy ezek közül csak azok lettek sikeresek, ahol a megfelelő gamifikációs dinamizmusok segítségével az alkalmazottak, illetve a vásárlók különböző játékostípusait tudták motiválni, hiszen a megfelelő dinamikák és érzelmi reakciók hiányában a játékosok egyszerüen "elugranak" (Robson et al., 2016).

\section{A kutatáshoz használt eszköz}

A gamifikáció hatásának vizsgálatához az első részben már említett Battlejungle nevű online alkalmazást használtuk, amely különböző formában elérhető. Az alkalmazás ingyenes funkciói kielégítik a legtöbb, KKV-kategóriába tartozó cég igényét, a nagyvállatok számára pedig személyre szabási lehetőségeket kínálnak, amelyekért már fizetni kell.

Ebbe az online platformba számos gamifikációs alkotóelemet integráltak a készítők azért, hogy a felhasználói élményt és az elköteleződés mértékét növeljék. Röviden most ismertetjük a Battlejungle által használt játékelemeket.

\section{A pontok}

A szolgáltatás gamifikált rendszere a $\mathrm{PBL}^{1}$-hármasra épül. A kutatásunkhoz használt szoftverben a felhasználók összemérhetőségére egy pontrendszer szolgál, melyet a Battlejungle rendszere ,, karmának” nevez, azaz a felhasználók karmákat gyüjtenek. A pontrendszer rögzít teljesítményalapú, valamint aktivitásalapú pontokat is. 
A teljesítményalapú pontok a különböző megmérettetéseken való részvétellel szerezhetők meg. Annak érdekében, hogy a játékosok motiváltak legyenek a minél több embert megmozgató események megszervezésére és az azokban való részvételre, a felkínált pontérték függ a szervezet (a rendszerben egy csoportosulásként megjelenő felhasználók összessége) és a bajnokság (megmérettetési eseménysorozat) létszámarányától, valamint figyelembe veszi az egy résztvevő által játszható meccsek átlagos számát, mely függ a bajnokság lebonyolítási módjától (pl. körmérkőzés, egyenes kiesés, vegyített stb.). Az alábbi képlet szemlélteti egy új résztvevő csatlakozása esetén a bajnokság befejezésekor kiosztandó karma növekményének kiszámítási módját.

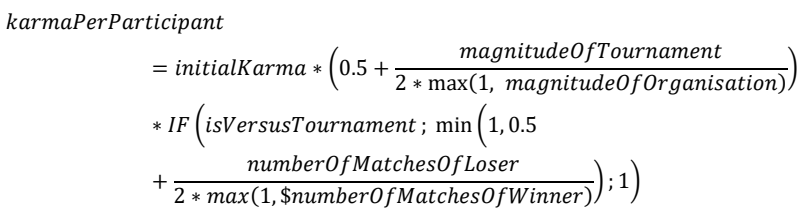

karmaPerParticipant: egy bajnokság befejezésekor kiosztandó pontérték növekménye egy új résztvevő csatlakozásakor,

initialKarma: kiinduló pontérték,

magnitudeOfTournament: a bajnokság résztvevőszámának 2-es alapú logaritmusának egész értéke,

magnitudeOfOrganisation: a szervezet taglétszámának 2-es alapú logaritmusának egész értéke,

isVersusTournament: igaz-e, hogy a vizsgált bajnokság Versus típusú,

numberOfMatchesOfLoser: az utolsó helyen végző játékos által játszható mecscsek száma,

numberOfMatchesOfWinner: az első helyen végző játékos által játszható mecscsek száma.

Ily módon minél több felhasználó vesz részt egy bajnokságban, annál magasabb pontszámokat kaphatnak egyegy mérkőzésük vagy eredménybejelentésük során, valamint annál magasabb az összesített pontérték (karma pool), mely a verseny lezárulta után a helyezések között oszlik szét (1. táblázat).

1. táblázat

\section{„Vegyített” lebonyolítási elvű bajnokság „karma pool"-jának résztvevőnkénti pontnövekménye egészértékre kerekítve}

\begin{tabular}{|c|c|c|c|c|c|c|c|c|c|}
\hline $\begin{array}{c}\text { Bajnokság(fó) } \\
- \\
\text { Szervezet (fó) }\end{array}$ & 2 & 4 & 8 & 16 & 32 & 64 & 128 & 256 & 512 \\
\hline 2 & 150 & & & & & & & & \\
\hline 4 & 113 & 150 & & & & & & & \\
\hline 8 & 100 & 125 & 150 & & & & & & \\
\hline 16 & 94 & 113 & 131 & 150 & & & & & \\
\hline 32 & 90 & 105 & 120 & 135 & 150 & & & & \\
\hline 64 & 88 & 100 & 113 & 125 & 138 & 150 & & & \\
\hline 128 & 86 & 96 & 107 & 118 & 129 & 139 & 150 & & \\
\hline 256 & 84 & 94 & 103 & 113 & 122 & 131 & 141 & 150 & \\
\hline 512 & 83 & 92 & 100 & 108 & 117 & 125 & 133 & 142 & 150 \\
\hline
\end{tabular}

Aktivitásalapú pontok olyan cselekvések elvégzése után járnak, amelyek a szervezettel vagy a rendszerrel történő foglalkozásra irányulnak, úgymint az oldal meglátogatása, az eredmény megosztása, vagy visszajelzés küldése.

\section{A jelvények}

Elsősorban a teljesítő és felfedező típusú játékosok számára kedveznek a rendszer által kínált különféle jelvények. A jelvények irányulhatnak versenybéli teljesítmény elérésére, időponthoz köthető eseményekre, valamint szocializációs tevékenységek végzésére is.

\section{A szintek}

A kutatásunkhoz használt alkalmazásban a játékosok különböző felhasználói szinteket érhetnek el, melyek az elért összesített pontszámaikon alapulnak. A felhasználói szintek az állatvilág témájára épülnek, 15 szint különül el, a Heroic Hamster-től egészen a Grand Gorilla-ig (ez utóbbiból maximum egy lehet szervezetenként). Az alkalmazásra adott személyes, kötetlen hangvételü visszajelzések alapján a felhasználói szint az egyik legkedveltebb gamifikált elem, felülmúlva ezzel a jelvényeket és a karmát.

Annak érdekében, hogy a felhasználó már az első belépésekor érezze, hogy fejlődik, az alapinformációkat bekérö és magyarázatokat felvonultató First Use Tour végén a játékos annyi karmát kap, mellyel sikeresen fellép a 2 . szintre (Sneaky Squirrel).

\section{Az előrehaladás és a ranglista}

Nagyon fontos a játékmechanizmus, mivel a játékos folyamatosan láthatja, hogyan áll. Ez egy állandó és azonnali visszajelzés a cselekvések jutalmazására. A kutatásunkhoz használt programban minden egyes verseny kapcsán megtalálható a játékos aktuális helyezése, valamint az összesített karma-értéke alapján a szervezeti rangsorban megtalálható helyét is megtekintheti. Annak érdekében, hogy a nem a legjobb 5-10\%-ba tartozó játékosokat ne demotiválja az alacsonyabb helyezés, a főoldalon a ranglistának csak a közvetlen környezete látható, magán kívül \pm 2 fövel.

\section{A közösségi interakciók}

A vizsgált alkalmazás közösségépítő vonala három fő részből áll. Az első a kommunikáció, mely a közösségi médiában is használt posztolásban, kommentálásban és hangulatkinyilvánításban valósul meg. A második öszszetevő az adott szervezetben megvalósult tevékenységek naplója, amivel nyomon lehet követni, hogy milyen események zajlottak le, milyen mérkőzéseket játszottak le, történt-e játékosok általi kommunikáció, indult-e új bajnokság, kik léptek szintet, milyen jelvényt osztottak ki stb. A harmadik pillér pedig a szolgáltatáson kívülre mutat, a felhasználó meg tud osztani bizonyos okleveleket és jelvényeket több közösségi médiumon keresztül.

\section{A gamifikált szolgáltatás hatásának mérőeszközei}

Az alkalmazás a felhasználók munkahelyi életvitelére gyakorolt hatását kétféle módon fogjuk vizsgálni. Először elemezzük a rendszer által gyüjtött adatokat, többek 
között a játékos pontszámát, szintjét, aktivitását, bajnokságokban való részvételét, ténylegesen lejátszott meccseinek számát. Szervezeti szinten a tagok között létrehozott kapcsolatok száma, sikeresen lezajlott vagy aktív bajnokságok aránya, közösségi funkciók használata (post, komment, like megosztás), aktív játékosok, preferált sportágak stb. segítenek az elemzésben.

A kutatásunk másik pillérét a felhasználóktól közvetlenül érkező, a szolgáltatás felületén feltett kérdésekre adott válaszok alkotják. Minden kérdés esetében 2-4 válasz kínálkozik fel, melyek közül egyet választhat a felhasználó. A visszajelzés 1-1 kérdés megválaszolásával történik, melyet egy elöre meghatározott kérdésbankból választunk ki a felhasználó számára attól függően, hogy milyen tevékenységet végzett éppen, a rendszer mely oldalán jár, és milyen hasonló jellegü kérdést válaszolt meg nemrég.

A kapott eredményeink pontosabb megértéséhez a Google Analytics által nyújtott adatokat is használjuk, ezek segítségével elemezzük a felhasználók lokalizációs, nem, kor és érdeklődés szerinti összetételét.

\section{A Kutatásunk résztvevői}

A Google Analytics szolgáltatás segítségével feltérképezhetővé váltak a Battlejungle felhasználói. A vizsgálat a 2017. február 1-je és 2017. április 30-a közötti időszakot öleli át. Az adatok alapját azon felhasználók által indított munkamenetek képezik, akik rendelkeznek fiókkal a szolgáltatásban, vagy időközben regisztráltak erre.

\section{A lokalizáció}

Az alkalmazás kereskedelmi bevezetése egyelöre Magyarországra korlátozódik, így az adott időszakban a munkamenetek száma láthatóan itt a legnagyobb (3352 db). A cég webes hirdetéseinek célországai fóként az európai országok és az USA, ily módon a második legtöbb munkamenettel bíró ország az USA (1067), majd őt követi Németország (802), az Egyesült Királyság (560) és Franciaország (237). Az első 10 között szerepel még a webes hirdetési célterületen kívül eső Ausztrália (42) és Új-Zéland (28).

\section{A Demográfia}

A 3. ábra A panelján bemutatott életkoreloszlás alapján azt kaptuk, hogy a szolgáltatást elsösorban a 25-34 éves korosztály használja $(55,2 \%)$, ám jelentős arányt képviselnek a 35-44 közöttiek is, ők alkotják a felhasználói bázis $27,3 \%$-át.

3. ábra

2017. február 1. és április 30-a között belépett felhasználók kor és nem szerinti megoszlása

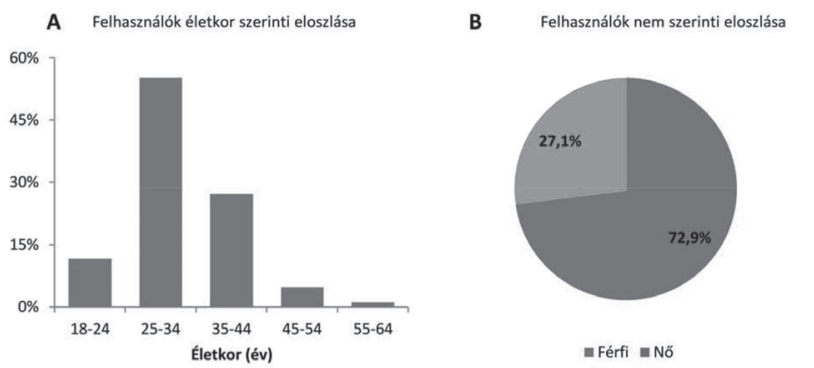

\section{Nemek}

A 3. ábra B panelján lévő nemek szerinti megoszlásból látható, hogy többségében férfiakból áll a felhasználói bázis $(72,9 \%)$, a nök csak egynegyedét teszik ki $(27,1 \%)$ ennek. Ezek az értékek némi eltérést mutatnak az átlagos amerikai játékosok nemenkénti megoszlásával szemben, ami betudható a regionális különbségeknek.

\section{A résztvevők munkahelyeinek piacon belüli szegmense}

A Google Analytics segítségével megnéztük a Battlejungle szolgáltatást használók munkahelyeinek kategóriáit. Vizsgálatunk azt mutatta, hogy közel egyenlő arányban képviseltetik magukat a különböző utazási $(8,7 \%)$ és a pénzügyi szolgáltatások területén dolgozók $(8,4 \%)$. Ezen kívül még az autóiparban (4,3\%) és a szoftverfejlesztéssel foglalkozók (3\%) részvétele számottevő.

\section{A kutatásban vizsgált szervezetek}

A Battlejungle szolgáltatás használatakor a felhasználóknak először létre kell hozniuk egy szervezetet, melynek keretei között különféle bajnokságokat, kihívásokat tudnak majd kiírni, és amelybe munkatársakat (további felhasználókat) tudnak felvenni, illetve meghívni.

Jelen kutatásban azokat a szervezeteket vizsgáltuk, amelyek 2017. április 30-áig legalább 10 fővel rendelkeztek, és legalább egy darab bajnoksághoz vagy kihíváshoz köthető, annak célját elősegítő teljesítményalapú aktivitást váltottak ki (pl. meccs lejátszása, futóeredmény rögzítése).

\section{4. ábra}

\section{A vizsgálatba bevont 20, legalább 10 fővel rendelkező szervezet iparági besorolása}

A

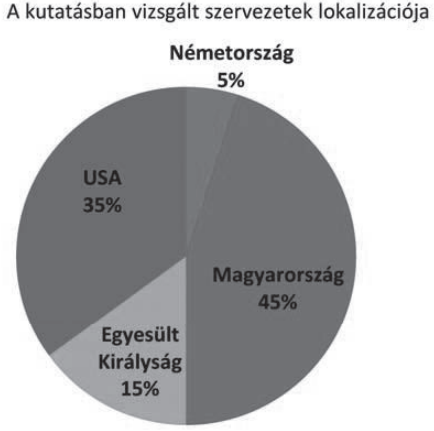

B

A kutatásban vizsgált szervezetek piacon belüli segmense

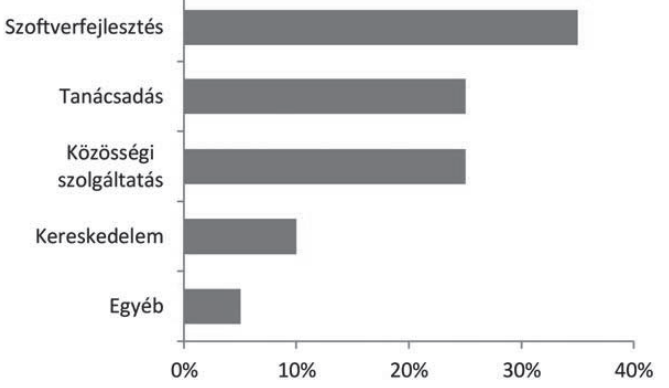


A fenti kritériumok alapján húsz szervezetet vizsgáltunk. Ezek létszáma 10 és 217 fö között mozog, és összesen 860 felhasználót foglal magába. A húsz szervezetből hat (576 fö) a Battlejungle üzemeltetőinek közvetlen megkeresése után, míg tizennégy szervezet (284 fö) organikus módon, azaz hallomás, hirdetés vagy PR-cikk kapcsán kezdte el használni az alkalmazást.

A 4. ábra A panelján ábrázoltuk a szervezetek területi megoszlását, ami összhangban van az összes felhasználó lokalizációs eloszlásával. A húsz szervezet iparági besorolásáról elmondható (4. ábra $B$ panel), hogy fóként az IT és a tanácsadás területén mozgó vállalatok fogékonyak egy ilyen jellegü online, közösségépítő szolgáltatás használatára.

Érdemes megfigyelni, hogy a húsz, a Battlejungle-t tartósan használó szervezet és a felhasználók munkahelyeinek piaci besorolása között eltérés mutatkozik. Míg a szoftverfejlesztés mindkettőben szerepel, addig pl. az autógyártás csak az egyedi felhasználók oldalán jelentkezik. Ennek oka lehet, hogy a felhasználók esetében gyakran több iparágat is feltüntet a Google Analytics, hiszen egy vállalkozás különböző szektorokban is dolgozhat, míg mi a vizsgált szervezeteket egyértelmüen kategorizáltuk.

\section{A szervezetek által indított bajnokságok}

A vizsgált szervezetek 106 bajnokságot indítottak 24 különböző sportágban, amelyek során 1329 mérkőzést játszottak le, és 2136 egyéni teljesítmény bejelentése történt meg. Megszervezésük és levezénylésük körülményességét az alábbi ötfokozatú skála segítségével csoportosítottuk:

1. mikrotételü beszerzést, vagy már meglévő mindennapos, egyszerű eszközt igénylő bajnokság,

2. kistételü beszerzést igényel a sport, és a bajnokság bárhol lebonyolítható,

3. közepes tételü beszerzést igényel a sport, és kisméretü belső helyigényt jelent a bajnokság,

4. közepes tételü beszerzést igényel a sport, közepes helyigényü a bajnokság, és kisebb csapatok összetoborzása szükséges,

5. nagy tételü beszerzést igényel a sport, nagy helyigényű a bajnokság, és nagy létszámú csapat toborzása szükséges.

\section{2. táblázat}

Az 5 legnépszerűbb sport a vizsgált 20 szervezet által indított bajnokságok alapján

\begin{tabular}{|c|c|c|}
\hline Sport neve & Körülményesség & Darab \\
\hline Asztalitenisz & 3 & 35 \\
\hline Csocsó & 3 & 10 \\
\hline Ügyességi játékok & 2 & 9 \\
\hline Futás & 2 & 7 \\
\hline Sakk & 2 & 5 \\
\hline
\end{tabular}

A bajnokságok körében elenyésző (6 db) a 4-es vagy 5-ös körülményességű esetek száma (tenisz, futball stb.). A ke- vésbé körülményes választások közül is az asztalitenisz, a csocsó és a könnyedebb hangvételü árkádjátékok (lépcsőzés, tésztatorony-építés, papírgalacsin-dobálás) a legnépszerübbek. Az adatokból leszürhető, hogy a cégek az olyan sporteseményeket preferálják, melyek inkább szórakoztató hangvételüek, közismert tevékenységek, és emellett nem igényelnek nagyösszegü ráfordítást. (2. táblázat)

\section{A felhasználók által adott visszajelzések}

A Battlejungle szolgáltatásban több helyen is lehetőség adódik visszajelzéseket adni. A visszajelzési rendszer a vizsgálat kezdeti idejével megegyezően (február 1-je) vált elérhetővé a felhasználók számára. A feltett kérdést befolyásolja, hogy az adott felhasználó mióta használja a szolgáltatást, milyen sportágú bajnokságokon vett részt, mikor válaszolt meg hasonló kérdést. A vizsgált szervezetek tagjaitól összesen 696 darab kérdésmegválaszolás érkezett. A feltett kérdések az alábbi öt témakörre bonthatók:

- a munkahelyi légkör változása,

- a szervezet tagjaival történő kapcsolatok száma és minősége,

- a sportolások gyakorisága,

- az eredménybejelentés utáni érzése,

- a szolgáltatással kapcsolatos vélemény.

3. táblázat

\section{A szolgáltatás által automatikusan feltett kérdések}

\begin{tabular}{|c|c|c|}
\hline Kérdés & Kategória & Megjegyzés \\
\hline $\begin{array}{l}\text { Hogyan változott a szervezeté- } \\
\text { nél a légkör a szolgáltatás beve- } \\
\text { zetése óta? }\end{array}$ & \multirow{2}{*}{$\begin{array}{l}\text { Munkahe- } \\
\text { lyi légkör } \\
\text { változása }\end{array}$} & \multirow{4}{*}{$\begin{array}{l}\text { Általános, } \\
\text { pozíció } \\
\text { szerint nem } \\
\text { korlátozott } \\
\text { megjelenésű. } \\
\end{array}$} \\
\hline $\begin{array}{l}\text { Hogyan változott a szerve- } \\
\text { zeténél a légkör az elmúlt } 30 \\
\text { napban? }\end{array}$ & & \\
\hline $\begin{array}{l}\text { Hány egyáltalán nem vagy } \\
\text { kevésbé ismert emberrel ismer- } \\
\text { kedett meg a Battlejungle-ön } \\
\text { keresztül az elmúlt } 30 \text { napban? }\end{array}$ & \multirow{2}{*}{\begin{tabular}{|l} 
A szerveze- \\
ti tagjaival \\
történő \\
kapcsolatok \\
száma és \\
minősége
\end{tabular}} & \\
\hline $\begin{array}{l}\text { Jobb-e a kapcsolata azokkal az } \\
\text { emberekkel, akikkel már ját- } \\
\text { szott együtt? }\end{array}$ & & \\
\hline $\begin{array}{l}\text { Többet sportol a szolgáltatás } \\
\text { bevezetése óta? }\end{array}$ & \multirow{2}{*}{$\begin{array}{l}\text { Sportolások } \\
\text { gyakori- } \\
\text { sága }\end{array}$} & $\begin{array}{l}\text { A belső rend- } \\
\text { szer föolda- } \\
\text { lán jelenik } \\
\text { meg. } \\
\end{array}$ \\
\hline $\begin{array}{l}\text { Elöfordult-e már, hogy [adott } \\
\text { sport]-ból többet üzött csak } \\
\text { azért, hogy a szolgáltatásban } \\
\text { rögzítse az eredményét? }\end{array}$ & & $\begin{array}{l}\text { Az (adott } \\
\text { sportú) } \\
\text { bajnokság } \\
\text { oldalán kerül } \\
\text { feltevésre. } \\
\end{array}$ \\
\hline $\begin{array}{l}\text { Mennyire volt számodra szóra- } \\
\text { koztató a meccs? }\end{array}$ & $\begin{array}{l}\text { Eredmény- } \\
\text { bejelentés } \\
\text { utáni érzése }\end{array}$ & $\begin{array}{l}\text { Meccsalapú } \\
\text { bajnokságok } \\
\text { esetében, egy } \\
\text { meccsered- } \\
\text { mény beje- } \\
\text { lentésekor } \\
\text { vagy elfoga- } \\
\text { dásakor jele- } \\
\text { nik meg. }\end{array}$ \\
\hline
\end{tabular}


Jelen kutatásban az első négy témakörbe tartozó kérdésekre adott válaszokat vizsgáltuk. A kérdéseket egyenként, a szolgáltatás felületének több pontján jelenítjük meg, és a válaszadás minden esetben opcionális. A felületen történő visszajelzésre leghamarabb a regisztrációt követő 2 hét letelte után kerülhet sor. A korlátozás indoka, hogy a rendszert még nem ismerő felhasználók ne tudjanak 1-2 alkalomnyi használat után olyan kérdésekre válaszolni, mely a szolgáltatás által okozott változást hivatott mérni. A változást kutató kérdéseket (típustól függően) 2-3 hét múlva a felhasználó újra meg tudja válaszolni. A feltett kérdések tartalmát, kategóriáját a 3. táblázat foglalja össze.

\section{A kutatásunk eredményei}

\section{A munkahelyi légkör változása}

Azon visszajelzések alapján (5. ábra A panel), amelyeket a „Hogyan változott a szervezeténél a légkör a szolgáltatás bevezetése óta/az elmúlt 30 napban?" kérdésekre adtak (87 db), kiolvasható, hogy a többség könnyedebbé, játékosabbá vált munkahelyi légkört tapasztalt (86,21\%).

Az aggregát adatok mellett azok időbeli változása a szolgáltatás hosszabb távú használhatóságát jellemzi. Az 5. ábra $B$ panel a válaszok a szolgáltatás bevezetése óta (vagy február 1-je óta, a visszajelzési rendszer implementálását követően, ha a szervezet már előtte is használta az alkalmazást) eltelt hetek átlagos értékelését takarja. Megfigyelhető, hogy 10+ hét elteltével is pozitív légköri változásokról számolnak be a felhasználók. A 11. héten látható átlagos „Változatlan” értékelés alacsony számú válaszai egy adott szervezetből érkeztek, így alakulhatott ki egy, a többi héthez képest kedvezőtlenebb értékelés.

\section{A kapcsolati háló méretének változása}

A kapcsolati háló kiterjedése (5. ábra $C$ panel) kapcsán a „Hány egyáltalán nem, vagy kevésbé ismert emberrel ismerkedett meg az alkalmazáson keresztül az elmúlt 30 napban?" kérdésre adott visszajelzések alapján a válaszadók 82,61\%-a ismerkedett meg legalább egy emberrel, közel harmaduk $(30,43 \%)$ pedig legalább három (részben vagy teljesen) ismeretlen emberrel teremtett kapcsolatot.

\section{A kapcsolati háló minőségének változása}

A kialakított kapcsolatok minőségére irányuló kérdésre (,Jobb-e a kapcsolata azokkal az emberekkel, akikkel már játszott együtt?") a válaszok több mint kilenctizede pozitív eredményröl számolt be (5. ábra $D$ panel). A válaszadók 52,94\%-a úgy érzi, kicsivel jobb lett a kapcsolata, 41,18\%-a az „Igen, sokkal jobb!” válasszal élt, 5,88\%-a változatlannak érzi, míg negatív változásról nem érkezett visszajelzés.

\section{A sportolási szokások változása}

A válaszadók sportolási szokásai kapcsán egyértelműen pozitív változásról szóló visszajelzések gyültek össze (6. ábra A panel). Arra a kérdésre, miszerint érzése szerint többet sportol-e a szolgáltatás bevezetése óta, 54,92\% (106 fö) a „Sokkal többet!” válaszlehetőséggel élt, további 22,28\% (43 fö) a „Kicsit többet” adta válaszul, míg $22,80 \%$ (44 fö) úgy érzi, nem változott a sportrutinja.
5. ábra

A munkahely légkörének és a kapcsolati háló méretének változása a vizsgált időszakban

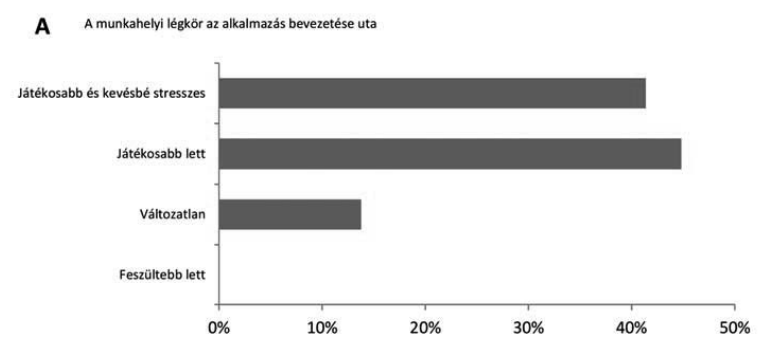

B
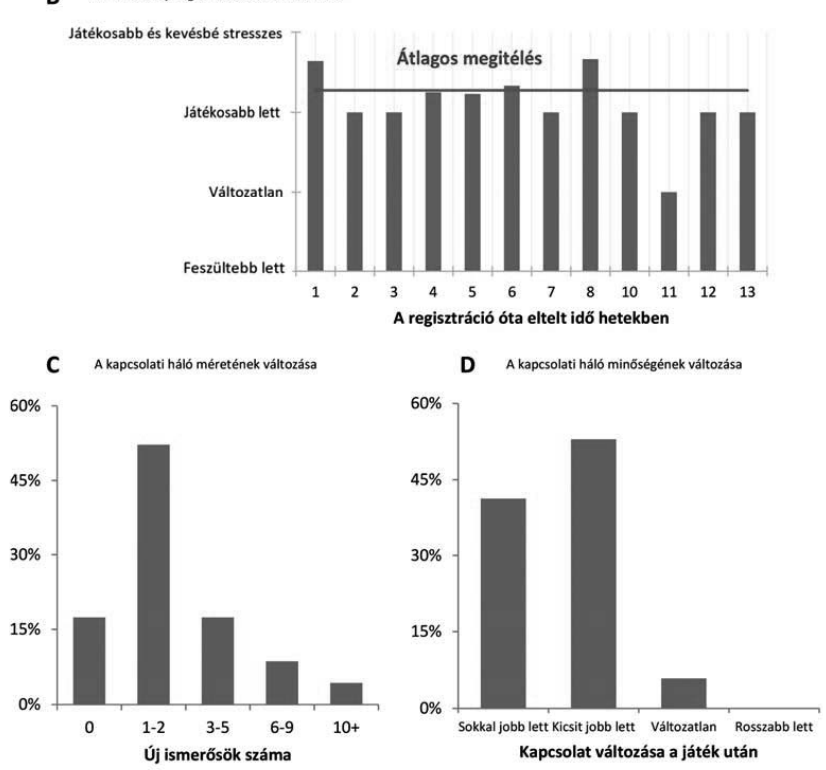

6. ábra

\section{A sportolási szokások változása a vizsgált időszakban}

A

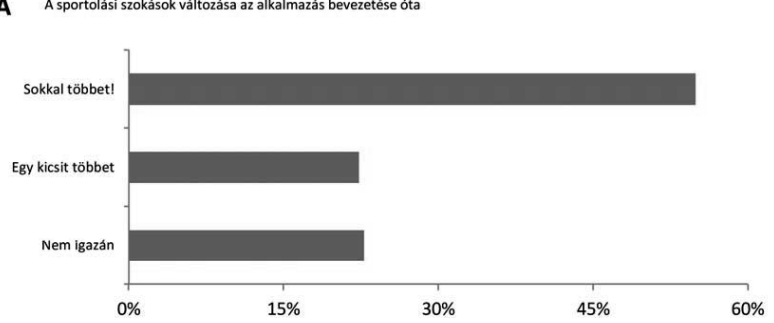

B

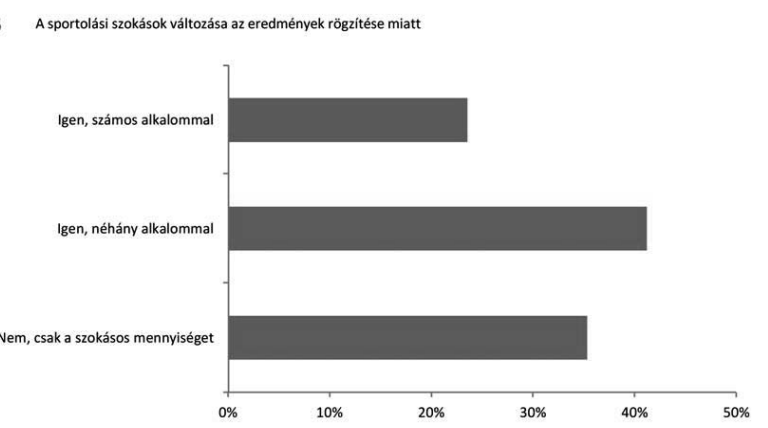


A sport jellegének vizsgálatából kiderül, hogy azon sportok esetén, melyek egyedül végezhetők (futás, úszás, biciklizés stb.), sokkal inkább jellemző a már meglévő rutin szinten tartása. Az ,egyéni” sportok esetében a válaszok $63,16 \%$-a állítja a változatlanságot. Ezzel szemben a társas sportesemények kapcsán (asztalitenisz, csocsó stb.) a véleménynyilvánítók $86,11 \%$-a nyilatkozott a pozitív irányú változásról.

A sportalkalmak gyakoriságának változására egy másik megközelítés szerint is rákérdeztünk az ,Előfordult-e már, hogy (adott sport)-ból többet üzött csak azért, hogy a szolgáltatásban rögzítse az eredményét?" kérdéssel ( 6 . ábra $B$ panel). Ezt a kérdést elsősorban a teljesítménymérésen alapuló sportok (úgymint futás, biciklizés) esetén tettük fel. A válaszadók 35,29\%-a jelezte, hogy a szokásos rutinját vezeti a rendszerben, azonban a felhasználók 41,18\%-a úgy vallott, hogy már néhányszor előfordult, míg 23,53\%-a az erős „Igen, többször is, inspirál engem!” válasszal élt. Ezek alapján állítható, hogy egy online szolgáltatás, mint külső motivációs eszköz közremüködésével sikerült belső késztetést ébreszteni a felhasználók egy részében.

\section{A hangulat feltérképezése}

Egy-egy lejátszott meccs után a játékosok hangulatát is mértük a „Mennyire volt számodra szórakoztató?” kérdés feltevésével. A válaszok egy 4-es skálán mozognak, ily módon a válaszadónak nincs lehetősége közömbös vélemény adására. A beérkezett vélemények 84,51\%-a a legpozitívabb értékelést választotta, további 9,86\%-a a válaszoknak volt 3 pont a 4-böl, a felhasználók 5,63\%-a adott csak 1-es vagy 2-es értékelést.

A válaszadók hangulatát összevetettük a játékosok szintjeivel abból a célból, hogy esetleges kapcsolatot tárhassunk fel a két tulajdonság között. A kérdésre adott játékosonkénti átlagos értékelés és a játékosok karma-szintje között 0,04-os korreláció mutatkozik, mely nem ad alapot fennálló kapcsolatra. Ebből azt a következtetést vonhatjuk le, hogy a megelégedett válaszokat adók eloszlása független a tapasztalattól, azaz ugyanúgy élvezte egy kezdő játékos a meccset, mint egy tapasztaltabb.

\section{Összegzés}

Kutatásunk során arra kerestük a választ, hogy a gamifikált elemeket tartalmazó online eszköz alkalmas-e, és ha igen, milyen mértékben a munkahelyi légkör javítására. Vizsgálatunkhoz egy olyan alkalmazást használtunk, amely a csapatépítéshez, sportbajnokságok szervezéshez nyújt segítséget. Így a sport eszközén keresztül építi a munkahelyi közösséget, segítve ezzel a vállalati kommunikációt, vagy akár egy új munkavállaló beilleszkedését a szervezetbe.

Kutatásunkban egy adott időszakban elemeztük a rendszer által gyüjtött adatokat, mint a játékos pontszámát, szintjét, aktivitását, bajnokságokban való részvételét, ténylegesen lejátszott meccseinek számát, továbbá a felhasználóktól közvetlenül érkező, a szolgáltatás felületén feltett kérdésekre adott válaszokat.
A vizsgált adatok alapján azt mondhatjuk, hogy a gamifikált elemeket tartalmazó alkalmazásunk használatakor a felhasználók jobb munkahelyi légkörről számoltak be és számos új embert ismertek meg. Vizsgálatunk továbbá azt mutatta, hogy a vizsgált szolgáltatással, mint külső motivációs eszköz segítségével sikerült belső késztetést is ébreszteni a felhasználókban a testedzés életvitelbe iktatására.

Elemzésünkben nem tértünk ki az esetleges regionális különbségek vizsgálatára, az egyes sportversenyek és a hozzájuk köthető motivációs tényezők feltárására, illetve a válaszok szezonalitásának vizsgálatára. E kérdésekre adott válaszok megtalálása jövőbeli kutatási irányaink.

\section{Jegyzet}

${ }^{1}$ Points, Badges, Leaderboards, azaz Pontok, Jelvények, Ranglisták

\section{Felhasznált irodalom}

Aon Hewitt (2017): 2017 Trends in Global Employee Engagement. http://www.aon.com/attachments/human-capital-consulting/2017-trends-in-globalemployee-engagement-report.pdf

Battlejungle (2017): https://battlejungle.com/

Battlejungle Support (2017): Battlejungle levels - Levels to be reached. http://support.battlejungle.com/knowledge-base/battlejungle-levels/\#levels-to-be-reached

Bunchball, Inc. (2010): Gamification 101: An introduction to the Use of Game Dynamics to Influence Behavior. http://www.bunchball.com/sites/default/files/downloads/gamification101.pdf

Burke, B. (2012): Gamification 2020: What Is the Future of Gamification? Gartner Inc., 2012

Carter, C. (2012): Gamification is serious business. Multilingual Industry Focus, Iss. June, p. 24-27.

Dixon, D. (2011): Player Types and Gamification. University of the West of England. http:/gamification-research.org/wp-content/uploads/2011/04/11-Dixon.pdf

Droga5ny (2011): Bing | Decode case study. https://www. youtube.com/watch? $\mathrm{v}=\mathrm{XNic} 4 \mathrm{wf} 8 \mathrm{AYg}$

ESA (2016): Essential facts about the computer and video game industry. http://essentialfacts.theesa.com/Essential-Facts-2016.pdf

Fromann, R. (2012): Gamification: épülöben a Homo Ludens társadalma? Budapest: ELTE TÁTK, Szociológia Doktori Iskola. http://www.jatekkutatas.hu/publikacio_html_files/publikaciok-gamification.pdf

Freshdesk: Integrated game mechanics: Get the boring out of customer support, http://freshdesk.com/scaling-support/gamification-support-help-desk

Gallup (2013): State of the American Workplace. Employee Engagement Insights for U.S. Business Leaders. http://news.gallup.com/businessjournal/162953/tackle-employees-stagnating-engagement.aspx

Harter, J. K. - Schmidt, F. L. - Hayes, T. L. (2002): Business-unit-level relationship between employee satisfaction, employee engagement, and business outcomes: a meta-analysis. Journal of Applied Psychology, 87(2), p. 268-279. 
Houtman, I. - Jettinghof, K. - Cedillo, L. (2007): Raising awareness of stress at work in developing countires: a modern hazard in a traditional working environment: advice to employers and worker representatives.

Hunicke, R. -LeBlanc, M. -Zubek, R. (2004): MDA: A Formal Approach to Game Design and Game Research. Nineteenth National Conference on Artificial Intelligence http://www.cs.northwestern.edu/ hunicke/MDA.pdf

Kenézi A. (2015): Gamification - a játékok alkalmazása a marketingben és a marketingoktatásban. Marketing \& Menedzsment, p. 36-50.

O’Donovan, S. - Gain, J. - Marais, P. (2013): A case study in the gamification of a university-level games development course. p. 242. http://dl.acm.org/citation. $\mathrm{cfm} ? \mathrm{id}=2513456.2513469$

Rab Á. (2012): A gamifikáció lehetőségei a nem üzleti célú felhasználások területén, különös tekintettel a közép-és felsőoktatásra. Oktatás-Informatika, p. 1-2.

Robson, K. - Plangger, K. - Kietzmann, J. H. - McCarthy, I. - Pitt, L. (2016): Game on: Engaging customers and employees through gamification. Business Horizons, 59(1), p.29-36.

SAPVoice (2011): The Gamification of SAP. https:// www.forbes.com/sites/sap/2011/03/04/the-gamification-of-sap/\#703c445435ed
Schaufeli, W. B. (2012): Work Engagement: What Do We Know and Where Do We Go? Romanian Journal of Applied Psychology, 14(1), p. 3-10.

Shuck, B. - Wollard, K. (2010) Employee Engagement and HRD: A Seminal Review of the Foundations. Human Resource Development Review, 9(1), p. 89-110.

Szabó A. (2016): A munkavállalói elkötelezettség növelésének hatása és lehetőségei. Opus et Educatio, 3(4)

Szombathelyi Cs. (2012): A munkahelyi jóllét kutatásának előzményei és jelenlegi megközelítése - A stressztől a jóllétig. Alkalmazott Pszichológia, 2012/3, p. 33-45.

Towers Perrin (2008): Closing The Engagement Gap: A Road Map for Driving Superior Business Performance. Towers Perrin Global Workforce Study 2007-2008, https:/c.ymcdn.com/sites/www.simnet.org/resource/ group/066D79D1-E2A8-4AB5-B621-60E58640FF7B/ leadership_workshop_2010/towers_perrin_global_ workfor.pdf

Werbach, K. - Hunter, D. (2012): For The Win. How Game Thinking Can Revolutionize Your Business. Philadelphia: Wharton Digital Press

$Y e e$, N. (2006): The demographics, motivations, and derived experiences of users of massively multi-user online graphical environments. Presence: Teleoperators and virtual environments, 15(3), p.309-329. 